\title{
THE STUDY OF CLASSIFICATION OF EVENT COMMUNICATION IN LIBRARY SPHERE
}

\author{
Ievgeniia Kyianytsia \\ Department of Advertising and Public Relations \\ Institute of Journalism of Borys Grinchenko Kyiv University \\ 18/2 Bulvarno-Kudriavska str., Kyiv, Ukraine, 04053 \\ Gane@i.ua
}

\begin{abstract}
The article is devoted to actualization of the library public relations, especially to introduction of the modern creative PR-arrangement as the main instrument of the library PR-portfolio, aimed at the maximal satisfaction of users and raise of the library image. Classification of PR-arrangements, most topical for the library activity that is directed on improvement of the library image among the general public and also influence the popularization of reading in whole is actualized in this article.

Socio-cultural sphere needs significant transformations and development for today, because it is a background of society cultural level formation. Thus, we understand the necessity of popularization of the libraries among public, raise of demand for library services, involvement of population to the arrangements, introduced at the library, because library it is socio-cultural institution that favors the raise of educational level and national consciousness of society. The library activity in the modern world must obligatory be demanded, because demand it is a certain frame of whole information-communicative system, and public relations are the one of its main elements. Just event communication is one of the main instruments of PR-portfolio form cyclicity of the whole library activity that must start from the user and be finished with it, because at the arrangement the direct process of communication that provides the two-vector character of "public relations" takes place.
\end{abstract}

Keywords: public relations, image, library, PR-arrangement, socio-cultural sphere.

\section{Introduction}

The formation of innovative approach to the library activity that would ground the use of PR-technologies is conditioned by the libraries integration into the new socio-cultural reality that is aimed at creation of the competitive services on informational market. Thus, the modern conditions favor the formation of new approach to service for library users that must save the client's time, direct him/her to the accurately structured bases on social, legal, economic questions, local self-government, entrepreneurial activity, cultural life, regional ethnography and so on. So, the one of the main requirements to the today library is the demand for library services, awareness of importance of visiting library, its multifunctionality and so on.

Satisfaction of these requirements is possible not only at the expense of using new approaches to the readers' servicing, cataloging, creation of new forms of the work (distant service using electronic form, service by chargeable or cement principle and so on) but also by formation of portfolio of such PR-instruments that would effectively serve for the modernization of library structures.

We must concentrate attention on the presence of unique library funds and significant methodical experience that must be useful at posing library as spiritual-educational center for the public. Just forming its place in informational society, creating the image of socio-responsible institution, demonstrating innovations, library must timely react and answer to the significant events in spiritual life of the country and society, offer the own non-standard arrangements for popularization of art literature, open the funds, actively interact with the different institutions and associations, widen these contacts for the raise of national consciousness of society and strengthening of civic position.

\section{Analysis of literary data}

The value of PR-technologies integration in the library activity is presented in the studies of the native and foreign scientists. Thus, in the work [1] the attention is paid to the convenience of receiving information by the public. The most effective forms, according to the author, are: "interpersonal communication, information in mass media, organization of press-conferences, briefings, 
"round tables", public open discussions, presentations and so on. Properly influencing the public, information affects it and can change the public thought about certain problem. The news about arrangements are transferred through the channels of reverse connection and used for the correction of idea and further activities. The other research, used in our work [2] indirectly determines the main causes that entail the necessity to use public relations in socio-cultural institutions. Such global case is post-modern situation, connected with new principles of cultural tastes, further development of mass culture, widening of recreational space and so on. Based on the survey [3], we can state that the content and directionality of the library organizational culture are conditioned by the examples of assistants' behavior in the different situations. The authors think that at transfer of library values the qualitative and not quantitative ones must prevail; strategic and social rates and only then utilitarian-pragmatic ones. This succession must be followed also within the initiative event communication in library institutions, using mainly the methods of socially oriented marketing.

Overwhelming majority of specialists consider public relations at the library as a conception of competitive fight, as ideology of cooperation and coordination of interests and at the same time as a technology of management of consciousness and mood of external public and within organization, at the level of social group, social layer, class and also - as a technology of promoting production (commodities, ideas, services, organizations, leaders) on political, economic, educational and cultural markets.

Thus, the main specialists of library sphere ground the position of library as counteragent of informational market that is a producer of informational products and services, consumer and mediator that, as opposite to the activity of other institutions, acts as a guarantor of humanistic traditions of social development and the mean of support of social homeostasis [4].

At the same time the aforesaid authors accent the necessity of creation of the separate subdivision in the library structures that must form the positive image, promote the library services in informational space, organize arrangements that would attract attention of all target audiences, from the average user to the media representatives [5].

So, having analyzed the cited materials, we can assume that the problem of organization of PR-arrangements of the new level is insufficiently studied.

\section{Aim and tasks of research}

The aim of our work is the analysis of classification of PR-arrangement in the library sphere and also the search of most effective types of event communication that would favor the popularization of libraries and reading in general.

For attaining the set aim the following tasks must be realized:

1. Analysis of PR-arrangements depending on aims, target audience and form of their realization.

2. Structuring of the event communication that corresponds to the understanding of modern librarian.

3. Revelation of the most effective arrangements that would provide the competitive functioning of socio-cultural institution.

\section{Results of research}

The significant advantages belong to the libraries that use marketing approach that allows attract the additional costs for the library development, to raise the general role of the library in state, region. But the practice and foreign experience demonstrate that the replenishment of the library budget is possible not only at the expense of commercial marketing but also due to the other forms and methods of the work.

The one of such methods is qualitatively created and carefully prepared PR-arrangement. Thus, the library arrangements like the other work directions must be realized on the planned base, because they are the starting point for the use of all other instruments of the library PR-portfolio. Just the interesting, creative arrangement attracts the public attention, increasing the number of readers, raising the interest of correspondent mass media, provoking interest in the local authorities and sponsors. 
Let's note the specificity of event communication, because the PR-specialists can not be satisfied with only spontaneous events that take place around their organization or institution. Their important task is the creation of events that would help to inform public like the separate verbal or non-verbal means or even better. The event communication is an effective form of connection with public. It needs the considerable training and organizational work, resources, participation of highly-qualified workers and so on. The one of French specialists talked about it: "The most complicated task is a creation of events; it is a sort of the squaring of circle for the specialists in communication" [5].

The complications of event communication and also its advantages are connected with the features of the special events and arrangements, laid in its base. They are sometimes called complex methods of public relations. The substantial understanding of PR-arrangements gradation is necessary for the further effective use of one or another form of event creation. Let's present this gradation just for that:

Special events - arrangements, carried out by firms and organizations for attracting the public attention to them, their activity and production. They can be very different but have several common features. Special events have a complex character, connected with use of many factors as preparation and realization of arrangement. There are the diverse techniques and means of establishing contacts with public and attracting attention to the problem that caused realization of this action.

The special events have concrete character, because the created event is based on the concrete aims and tasks that need solution. The special events have exclusive character, because each event is original, specially organized for the solution of certain task and usually can not be duplicated. Even when the form of event (exposition, conference and so on) is repeated, it is a new exposition, conference and so on each time. There are no similar people and there are no similar events too, each one is unique and original.

The event communications have the controlled character. This feature of event communication is connected with the previous one and is its continuation, because the planned character of event provides also the control over its realization. The specialists think that the possible derivations from scenario must be foreseen in proper time. The surprises and improvisations for organizers of special events must not take place. It is recommended to leave them for public only. The event communication is obligatory attended with informational support [6].

The special event it is not always complicated and expensive arrangement. It can be rather simple action. For example, announce of a new book or creative work of the young promising author. There are several types of special events, created by public relations services.

Presentational events - events, directed on the general acquaintance with the firm, aimed at demonstration of the activity of organization or institution, its commodities or services to the public, they are always connected with the new aspects or stages of activity of the firm (opening of institution or its workshop, department, starting of the issue of new commodity, realization of service, entrance to the new market and so on). They have occasional character. This type includes: ceremonies of opening, presentations, open days.

Demonstrative arrangements there are arrangements, directed on acquaintance with the concrete activity of organization and types of its production. Their main aim is advertising of commodity. The most spread type of such arrangements is expositions, demonstrations of fashion, gastronomic demonstrations, excursions and fairs. They must be regular (monthly, annual expositions and fairs, permanent expositions and so on). They can be usually used by the firms of productive or trade type.

The one of most successful demonstrative arrangements at the library is the exposition-fair, but it can be connected with series of problems such as: informing - giving population the exhaustive information about the library resources and services, their properties, quality and so on; attraction of consumers' attention to the library-informational sphere - fixation of users' interest on the certain services of certain libraries, acquaintance of public with the fact of library existence as the modern, dynamic and powerful service institution; formation and fixation of the positive public opinion - expositions allow deepen the positive attitude of population and priority categories of the users to the library activity, create the base of reputation for the further strengthening of confidence to it; creation of attractive image - at presentations of book expositions the library is mainly 
connected with positive emotions, pleasant impressions and so on: stimulation to the use of libraryinformational services and products - the staff moderately offer the correspondent arguments. Practically all components of communication mechanism are involved in the process of organization of book exposition; the effective system information about documents and library services is provided by demonstration, consultations, recommendations, responses and other. Thus, expositions are rather complicated marketing instrument that allows combine telemarketing, advertising, competitions, holidays, other methods of popularization of the document fund and library services; virtual expositions and so on [7]. The following types of expositions are most popular:

Author exposition - book exposition, which author is a worker or user of the library.

Exposition-quiz, exposition crossword. The aim of expositions is to attract the users' attention to the certain topic. The librarian makes questions, which answers can be found in books, presented on exposition.

Exposition-discussion. The literature that elucidates problem from the different points of view and allows think about historical, socio-cultural events, about famous persons and their activity must be presented on exposition.

Exposition - dialog - correspondence conversation of user and librarian.

Exposition - competition - the works of winners (participants) are exposed at summarizing.

Exposition on remarkable and memorable dates informs and elucidates materials about the remarkable events, holidays, jubilee dates and so on.

Exposition on topical problems - choice of the interesting "hot" topic.

Exposition of new incomings aimed at informing users about new documents - books, electronic, periodical issues, video-materials, received by the library.

Exposition of one book (journal, newspaper, publication) interests user with concrete document by creation of exposition that includes information, for example, about the author of the book.

Exposition-rating is based on the assessment of books by the users.

Exposition-vocabulary explains the meaning of certain terms, notions and gives additional information about them.

Exposition-hobby. Exposition is formed together with user, is devoted to his/her interests.

Exposition-presentation - synthesis of library and museum expositions.

Exposition-installation it is a spatial composition, constructed of the different elements - books, periodical, electronic production, subjects of everyday use, visual information and so on.

Genre exposition attracts consumer's attention to the literature of certain genre, interests, stimulates to reading.

Personal exposition attracts users' attention of the personality, stimulates to know about it as more as possible. Traditionally the personal exposition includes sections that talk about the life of person, his/her activity, creative work. It is expedient to use photo-materials [8]. The new genre - virtual exposition - the synthesis of traditional (documental) and electronic presentation of information is popularized. It is created for remote user, who is beyond the library, uses the library services distantly and wants to receive informational service. Such exposition does not give user a possibility to acquaint with books that is to use them physically [9].

At the same time the virtual book exposition allows user acquaint with the presented documents in proper time and express the own thought about them and librarian direct the user's attention on the additional informational sources, accessible in the net. It popularizes the library fund, offers to interest in topic, present the notable book like the traditional library exposition.

The use of virtual expositions in the library practice allows solve the series of problems that can not by solved by the traditional methods.

There are especially:

- ensuring of saving documents;

- efficiency of organization of exposition and possibility of its permanent replenishment with the new documents;

- presentation of documents in the necessary number of tittles;

- unlimitedness of the term of exhibiting of documents; 
- possibility of review of the content of separate documents, especially, collections of scientific works and illustrations;

- elucidation of content of the presented issue using abstract;

- presentation of documents that are absent in the library funds but have certain importance for elucidation of the offered topic;

- possibility of distant review of exposition in any time (24 hours a day, 7 days a week).

The users of virtual exposition can receive the full information on interested topic without hurry, temporal or geographic limitations and costs, typical for traditional expositions, visually acquaint with informational resources and receive other additional information. It undoubtedly favors the address of users to the library resources, increase of their activity as to the visiting library.

Demonstration of the book expositions allows attain the series of communicative aims: provide the effective advertising, strengthen contacts with mass media and set the reverse connection in communication with users. The users' acquaintance with book exposition and library can be transformed into the bright show that undoubtedly favors the setting and support of the long-term relations with mass media representatives and public.

The opening of book exposition is generally an event, favorable for the meetings of administration and workers of the library with representatives of authorities and business, for solution of the separate business problem, setting of contacts with the future sponsors and friends of the library.

Exposition it is a base of creation of positive image of both library itself and its leaders at the expense of offering citations, professional references, phrases on the different general cultural problems. Because the more interesting is the first person of the library by his/her professional and personal qualities, the more attractive for public are the library arrangements.

Exposition must be convenient for perception by the user in web-space and can include the following types of information [9]:

The data about issue: visual (the picture of cover, digitized parts of book: preface, introduction); bibliographic data (bibliographic registration+ciphers of the library fund that presents exposition); analytic information (abstract, summaries to the issues, critiques, readers' responses); digitized parts of the book (sections, most interesting fragments and so on); references on the full texts if they are accessible in the library or Internet.

Informational arrangements - events, created to receive and widen information. Their main aim is the spread of ideas and setting of contacts with the competent persons or mass media representatives. There are conferences (especially, scientific ones and press-conferences), "round tables", meetings (for example, meeting with electors), sittings, mass meetings (mean that is used only by political parties and public organizations).

The one of most effective arrangement for promoting the library activity is a conference (from Latin - to gather at one place) - meeting, council of representatives of states, social groups and even separate persons (scientists, practicians) for discussing the different questions. The workers of public relations are interested in conferences as in the additional mean: conference with mass media representatives - press-conference and conference as an independent event, directed on the solution of the complex of tasks and especially promotion of ideas; setting of contacts with the competent persons and specialized institutions and organizations; as publicity tool (way of popularization of organization and its activity). Thus, the main task of press-conference is a setting of contacts with mass media. The conferences differ: by the composition of participants - scientific, scientific-practical; international, national; press-conferences, briefings and so on; by the topic-scientific, political, economic, ecological, on the problems of international relations and so on; by the place of holding or means of communication, used for them - conferences with personal representation, correspondence conferences, electronic and teleconferences [8].

Leisure arrangements - the events, which creation is directed on the joint organization of the free time of firm - hostess and its guests. Their main aim is the setting or support of contacts with public representatives. They can be connected with certain holiday dates (state, local, jubilee dates of organization of institution, the ones of its workers). They can be used by firms and organizations of the different time with concrete aims. The most spread forms of leisure arrangements are levees, dances, basket dinners, game shows, competitions, lotteries. 
Presentation it is a demonstration of person, firm or service to the public. The main aim of presentation is a transfer of information and ideas to convince the certain groups of people to accept or review their opinion; to make certain action or decision or refuse them. In practice the presentations are usually realized, when the new library subsection or branch is created or offices in other regions are opened, when the library tries to acquaint public with the new directions of its activity. Presentations are usually held occasionally, if it is necessary. The separate libraries practice the annual presentations, oriented on demonstrations of the new achievements of previous year.

It is known, that organization and conducting of presentations need the active participation of not only the PR representatives but also the leaders of libraries and workers of the other structural subsections of institution. The main presentation team must include at least three persons: responsible for presentation; specialist on the subject of presentation (commodities, services and so on); specialist, who knows and studies the audience, its needs, hopes and strivings.

Because the important factor of success of arrangement is determination of concrete public groups, that presentation is oriented on (that are wanted to be informed). The solution of this task flows from the results of segmentation of the market of users of information about our organization.

Open days. For conducting this arrangement it is necessary to prepare beforehand the detailed scenario with appointment of person, responsible for each position. The open day must be widely reported in mass media. In the rooms for guests it is expedient to place stands with information about the library work, illustrative material. The leader of institution gives information about activity of organization and answers the questions of journalists, then the chiefs of departments add the main information in their reports, then the excursion in institution is realized. At the end the stand-up party or degustation for guests can be organized.

Such work forms as literature-musical eves, creative meetings, thematic master-classes that favor the development of readers' talents, remain topical. The concert performances on the offered topic are possible within the leisure arrangement [6].

At the end we would like to pay attention to the preparation of any arrangement and to the resource base that must ensure such type of communication because there is also a question about timing, human resources, technical support and so on. So:

1. The most accessible and less laborious in the aspect of time spending and preparation are the aloud reading, literature review (review-conversation, review at exposition, review-lecture, quiz).

2. Arrangements that need significant preliminary preparation: writing of scenario, provision of requisites, preparation of staff are literary game (brain-ring, trip on stations, literary lotto, literary auction, quest and so on), oral journal, press-conference, competition.

3. Arrangement that in addition to preliminary preparation need significant individual work with participants, so, more time, financial support, qualification of workers are CFS, literary composition, literary court, literary holiday (sittings, literary levee, literary eve, literary dance), meetings in the literary parlor, readers' conferences [10].

From our point of view such arrangements must stimulate the general public to become the active user of library services.

\section{Conclusions}

The study was directed on the solution of the following tasks:

1. It was proved, that PR-arrangements are essentially differ and depend on both strategic aim of socio-cultural institution and on tactic task that is solved by this arrangement. We also revealed that the difference of event communication is also in the presence of resources, time, creative component, informational and technical support. All these components are reflected in forms and perfection of planned and realized arrangements.

2. The types of PR-arrangements were classified in a certain way, the main ones, from our point of view are: special events, presentational arrangements, informational precedents and also leisure sessions. The study of all aforesaid forms of arrangements is very important for the modern librarian, because he/she must not only initiate the event but also have a possibility to ensure its qualitative realization. 
3. The most interesting and intellectually and emotionally filled arrangements were revealed especially: conferences and disputes, where the mutual understanding is attained by creation of atmosphere of mutual respect and free self-realization in audience. At the same time such arrangements favor the attraction of all public layers to the event communication: readers, users, representatives of state and public organizations, ideological leaders and mass media.

Let's summarize: at topical, interesting and creative arrangements takes place communication, directed on convincing the collocutor in the correctness of own position and attracting to cooperation; the contact of different thoughts and positions, their grounding and strengthening take place that favor the acquisition of communicative experience, activate the rational activity, lead to the formation of new knowledge and understandings. Comparing the contradictory judgments, the participants of discussion try to attain the common idea, find the joint solution, establish truth. The success of discussion largely depends on the personality of librarian, especially his/her communicability and communicative competence. It is necessary to care about the dynamic communication in multiple audience because its attention concentrates, first of all, on conversation with an interesting or paradoxical content. There is no place for mentorship - only joint creative work, readiness to perceive the new information, tolerance, tact, sense of humor, self-criticism.

\section{References:}

[1] Abankina, T. V. (2001). PR Nekommercheskoj organizacii: teoreticheskie osnovy sovremennyh PR-tehnologij i modelej kommunikacii. Muzej budushhego. Available at: http://future.museum.ru/ part01/010501.htm

[2] Njushenkova, M. (2002). Imidzh organizacij social'no-kul'turnoj sfery. Prakticheskij marketing, 2. Available at: http://www.cfin.ru/press/practical/2002-09/05.shtml

[3] Kljuev, V. K., Jastrebova, E. M. (1999). Marketingovaja orientacija bibliotechno-informacionnoj dejatel'nosti. (Marketing v sisteme upravlenija bibliotekoj). Moscow: Gosudarstvennyj Universitet kul'tury i iskusstv, 144.

[4] Davydova, I. (2008). Innovacijna polityka bibliotek Ukrayiny: zmist ta strategiyi rozvytku v informacijnomu suspilstvi. Kharkiv: Kharkivs'ka derzhavna akademija kul'turi, 24.

[5] Barabash, S. (2013). Zv'yazky z gromadskistyu v systemi socialno-komunikacijnoyi dilnosti biblioteky vyshhogo navchalnogo zakladu. Kyiv: nacionalnyj universytet kultury i mystecztv, 26.

[6] Dubrovina, L., Onishhenko, O. (2009). Bibliotechna sprava v Ukrayini XX st. Kyiv, 309.

[7] Bulatova, S. N. (2001). Imidzh biblioteki. Bibliotechnaja zhizn' Kuzbassa, 1 (31), 125-127.

[8] Pochepcov, G. G. (2000). Kommunikativnye tehnologii dvadcatogo veka. Moscow: «Reflbuk», Kyiv: «Vakler», 152.

[9] Trachuk, L. (2007). Virtualna vystavka : nova posluga biblioteky. Visnyk knyzhovoyi Palaty, $11,36-38$.

[10] Smit, P. et. al. (2001). Kommunikacii strategicheskogo marketinga. Uchebnoe posobie. Moscow: «JuNITI-DANA», 746. 